The Chinese Enlightenment Intellectuals and the Legacy of the May Fourth Movement of 1919 VERA SCHWARCZ

"An inspiring book about an inspiring event. Schwarcz demonstrates convincingly that the significance of the May Fourth Movement is not restricted to the past history of China." $\$ 37.50$ -Chow Tse-tsung

\section{Making Revolution}

The Communist Movement in Eastern and Central China, 1937-1945

\section{YUNG-FA CHEN}

"This book offers a far fuller and more convincing description of Chinese Communist wartime activities than any other secondary work. It will be of great value to scholars of Chinese history and politics."

$\$ 60.00$

—Elizabeth J. Perry, University of Washington

\section{The Commercial Revolution} in Nineteenth-Century China

The Rise of Sino-Western

Mercantile Capitalism

\section{YEN-P'ING HAO}

Hao examines China's commercial revolution and evaluates its effect on the economy and society of China. By focusing on the longneglected field of modern Chinese commercial history he helps us to understand China's recent rapprochement with the West. $\$ 37.50$

\section{Peasant Protests and}

\section{Uprisings in Tokugawa Japan} STEPHEN VLASTOS

Vlastos investigates the changing patterns of peasant protest in the Fukushima area. He shows that peasant mobilization was restricted both ideologically and organizationally, and peasants did not become a prime moving force in the Meiji Restoration. $\$ 20.00$

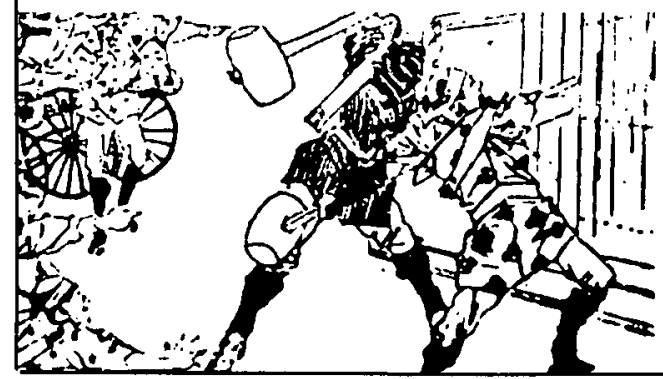

\section{Trans-Himalayan Traders} Economy, Society, and Culture in Northwest Nepal

\section{JAMES F. FISHER}

Tucked away in an obscure fold of the Himalayas in northwest Nepal, the trilingual Magars of Tarangpur are a cultural, linguistic, and economic hinge between the Tibetan north and the Nepali south. This fresh and richly-detailed study analyzes their agricultural and trading economy and their syncretistic culture. $\$ 35.00$

\section{Roses and Thorns}

The Second Blooming of the Hundred Flowers in

Chinese Fiction, 1979-80

\section{PERRY LINK}

New in paper- "Link has chosen the stories carefully to give as broad and interesting a sample of writing in China as possible... the translators have done an admirable job." $\$ 9.95$ paper -Far Eastern Economic Review

\section{Reform and}

\section{Revolution in China}

The 1911 Revolution in

Hunan and Hubei

\section{JOSEPH W. ESHERICK}

New in paper-" A fine example of Chinese provincial history as well as a timely attempt to rethink some of the issues underlying the 1911 revolution." - History $\$ 12.95$ paper

\section{Kinship and Marriage in Burma \\ A Cultural and Psychodynamic Analysis \\ MELFORD E. SPIRO}

New in paper- "Necessary reading for all Southeast Asia specialists."-Oceania $\$ 12.95$ paper

At bookstores or call toll-free 800-822.6657. Visa and MasterCard only. University of California Press Berkeley 94720 


\section{LEXINGTON BOOKS}

THE MANNER OF GIVING Strategic Aid and Japanese Foreign Policy

Dennis T. Yasutomo, Smith College

This pathbreaking book focuses on Japan's new foreign policy-economic aid. The author explores questions raised by the politicization and globalization of aid policy, including: Why and how did strategic aid emerge so quickly in Japan, and how strong is the domestic consensus on aid policy? What is the exact relationship between economic assistance and defense policy? Studies of the East Asian Institute, Columbia University.

ISBN 0-669-12894-5 April 160 pages ca. $\$ 22.00$

\section{FRAGILE INTERDEPENDENCE}

Economic Issues in U.S.-Japanese Trade and Investment

Thomas A. Pugel, editor, New York University, with Robert G. Hawkins

The growing economic interdependence of the U.S. and Japan continues to bring substantial benefits to both countries. But the economic relationship is also a fragile one, and it has never been stormier. In this book, American and Japanese experts from government, business, and academia provide balanced and thorough evaluations of this special relationship, predict its future course, and suggest how the conflicts can at least be managed, if not wholly resolved. ISBN 0-669-12263-7 288 pages $\$ 30.00$

\section{FINANCIAL POLICY AND REFORM IN PACIFIC BASIN COUNTRIES} Hang-Sheng Cheng, editor, Federal Reserve Bank of San Francisco

This comparative study of the Pacific Basin countries' experiences with financial deregulation sheds light on the dynamic interaction between market forces and government financial policies. The experienced contributors find that recent high and unstable inflation rates, rapid technological innovations, and international financial integration have universally undermined various national objectives, creating distortions in national financial activities as markets evolve to bypass the regulations.

ISBN 0-669-11206-2 384 pages $\$ 33.00$

\section{SECURITY INTERDEPENDENCE IN THE ASIA PACIFIC REGION}

James W. Morley, Columbia University, editor

Foreword by Gerald W. Curtis

This book concentrates on the complex security relationships between the U.S., Japan, South Korea, Taiwan, and the countries of ASEAN. Noted contributors examine the regional and subregional strategic issues, the rationales guiding them, and domestic influences on security relationships. Studies of the East Asian Institute, Columbia University.
ISBN 0-669-13090-7
May 192 pages
ca. $\$ 23.00$

\section{LEXINGTON BOOKS \\ D.C. Heath \\ 125 Spring Street \\ Lexington, MA 02173}

DPHeath

A reytheon Company

(617) 860-1204 or 1-800-334-3284 


\section{The Compelling Image}

Nature and Style in Seventeenth-Century Chinese Painting JAMES CAHILL

"A generously illustrated book, extraordinarily rich in insights, ideas, and information ..."

-Journal of Asian History

"Among the most important works on later Chinese paintings to appear in any Western language. It certainly will become a major statement about the impact of Chinese theory on the paintings of the seventeenth century." -Thomas Lawton, Director, Freer Gallery

Charles Eliot Norton Lectures

Belknap

$256 \mathrm{~b} / \mathrm{w}, 13$ color halftones, 2 maps

$\$ 14.95$ paper

at bookstores or from

HARVARD UNIVERSITY PRESS

Cambridge, MA 02138 


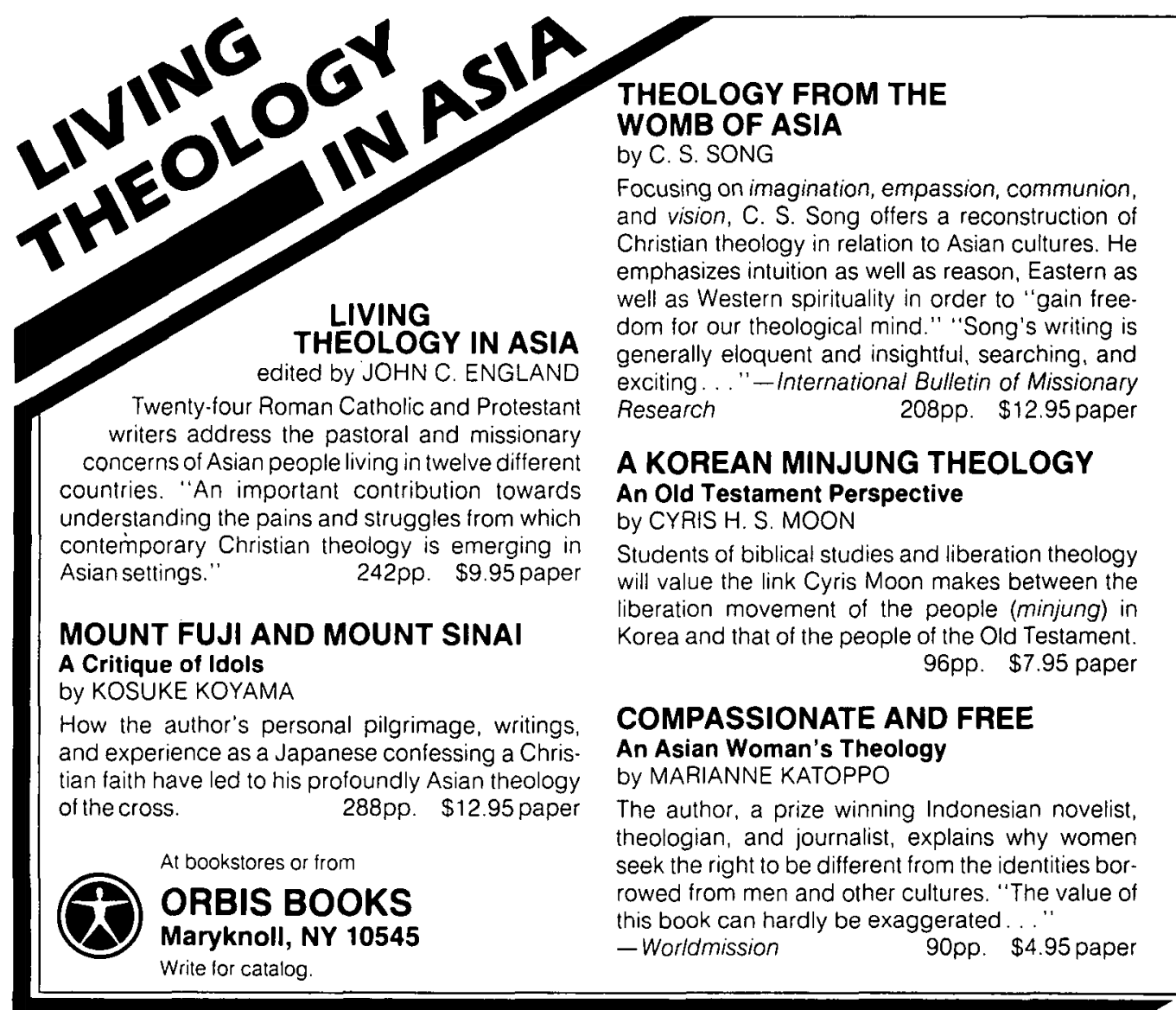

\section{XIN TANG: NEWCHINA}

\section{A Journal of Romanized Mandarin Number $7 \quad$ Summer, 1986}

\section{Special Enlarged Issue Focussing on a Comparison of Pinyin and Gwoyeu Roma Tzyh (National Romanization)}

contents include: Consensus of the Meizhou Zhongguo Wenzi Gaige Cujinhui (Association in America for the Promotion of Chinese Language Reform); illustrated narrative by Rui Lobin; biographical sketches of Chinese language reformers; Zhuang romanization; selection of classical Chinese, poetry, letters, book reviews; articles by Yuen Ren Chao, Zhou Youguang, Yin Binyong, John DeFrancis, Li Leyi, Elling Eide, David Jordan, and others.

\section{$\$ 10.00$ Individuals $\$ 15.00$ Institutions}

Order from: Institute for Advanced Communications, P.O. Box 254, Swarthmore, PA 19081 Back issues of XIN TANG are available at $\$ 2.50$ each.

Sino-Platonic Papers, 1

(February, 1986)

"The Need for an Alphabetically Arranged General Usage Dictionary of Mandarin Chinese: A Review Article of Some Recent Dictionaries and Current Lexicographical Projects"
by Victor H. Mair
\$2.50 Order from: Department of Oriental Studies, University of Pennsylvania/CU, Philadelphia PA 19104-6305 


\section{An exciting new series on the exotic culture and history of the East}

\section{OXFORD IN ASIA PAPERBACKS}

This series of adventure stories, travelogues, and studies of the land and peoples of China and East Asia brings this area vividly to life for the Western reader. Selected for their importance and the quality of their writing, the books in this series constitute $a$ small library of delightful, informative reading in which students. scholars, and travelers can discover the rich cultural heritage of the East.

\section{BAYONETS TO LHASA \\ PETER FLEMING}

This intriguing account of the

Younghusband Mission to Lhasa of

1903-04 describes one of the most

bizarre episodes in British imperial history.

$345 \mathrm{pp} . \quad \$ 8.95$

\section{THE SIEGE AT PEKING}

PETER FLEMING

Peter Fleming gives a gripping

account of the Siege of Peking, 1900.

which lasted 55 days and brought to

a head the crisis in the Celestial

Empire's relations with the outside

world.

$320 \mathrm{pp}$. halftones, maps $\$ 8.95$

\section{THE HEAD-HUNTERS OF BORNEO}

CAROL BOCK

Bock's account of his travels in Borneo

and Sumatra in the 1870 s includes

both descriptions of the natives'

well-known head-hunting pursuits

and vivid portraits of contemporary

life and local flora and fauna.

$370 \mathrm{pp} ., 30$ color plates $\$ 8.95$

\section{THE FIELD BOOK OF A \\ JUNGLE-WALLAH}

Shore, River and Forest Life in

Sarawak

CHARLES HOSE

This is a delightful description of nature and man's place in it, based on Hose's 23 years of service in

Sarawak, in which he established himselt as a naturalist and ethnologist of international standing.

$392 \mathrm{pp} .32$ halftones.

l color plate $\$ 8.95$

\section{ANGKOR \\ GEORGE COEDES}

Originally published in French in Hanoi, in 1943, this book is an introduction to the background of this ancient capital and the fascinating Khmer civilization.

118 pp. 22 halitones. maps $\$ 7.95$

\section{BOROBUDUR}

JACQUES DUMARCAY

Borobudur in Central Java is one of the largest religious monuments in the world. Dumarcay, a consultant architect on the monument's restoration. here describes Borobudur's architecture and symbolism and places it in the context of the religion of eighthcentury Java.

72 pp., 20 halftones, 7 color plates $\$ 7.95$

\section{JAVANESE WAYANG KULIT} EDWARD C. VAN NESS and SHITA PRAWIROHARDJO Wayang Kulit - the shadow play performed with puppets - is one of the oldest continuous storytelling traditions in Java. This is the first account of the subject for the general reader, explaining its importance in the everyday lite of the Javanese. 95 pp., 33 halftones, 45 color plates $\$ 7.95$

\section{JAVANESE GAMELAN}

JENNIFER LINDSAY

This book explains the instruments, musical form and social importance of gamelan music, a music indigenous to Central Java that is now being taught around the world.

59 pp. 18 halftones. 32 color plates $\$ 7.95$

Available at better bookstores or directly from

OXFORD PAPERBACKS

Oxford University Press

200 Madison Avenue - New York, NY 10016 


\section{Trade Unions in China: 1949 to the Present}

\section{By LEE LAI TO}

This book is an in-depth study of the structure and leadership of the All-China Federation of Trade Unions - the largest mass organization which aims at representing the interests of the laboring class in the People's Republic of China. Special attention is paid to the relations between the union system and the Party and state to find out the circumstances and factors which affect the roles and autonomy of unions in China. While the period of analysis starts from 1949, events before 1949 are summarized at the beginning of the book so as to provide a backdrop for the research into the contemporary scene.

1985 Limp $\$ \$ 20.00 / U S \$ 11.00$

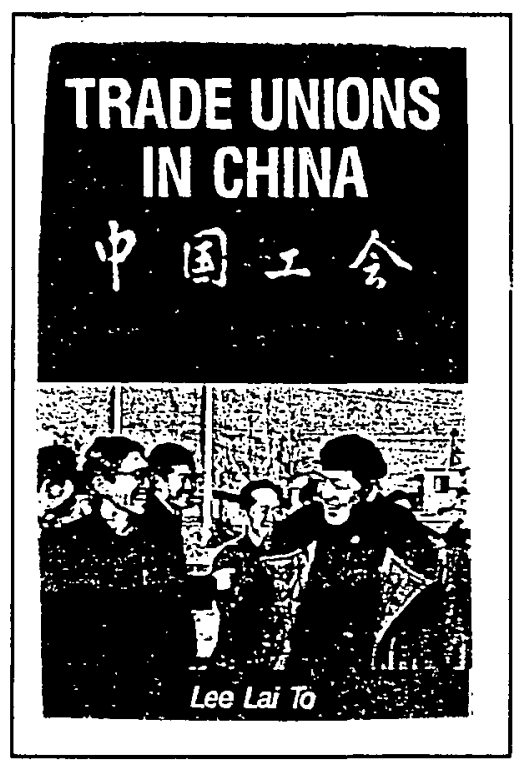

\section{China and the ASEAN States: The Ethnic Chinese Dimension}

\section{BY LEO SUR YADINATA}

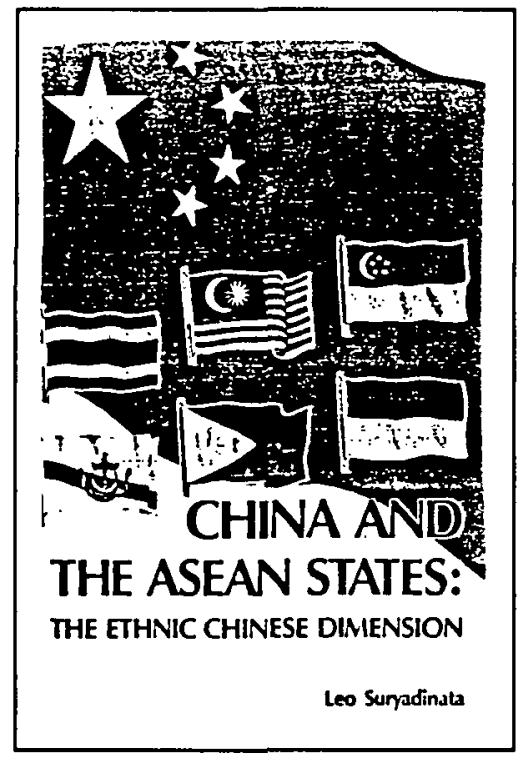

This book focuses on China's foreign relations with Southeast Asia with special reference to the ethnic and political dimensions. It deals with the reactions of Southeast Asian governments, especially those of ASEAN, to China's foreign policy, in general, and towards its ethnic Chinese policy, in particular. The position of the "Overseas Chinese" in the foreign policy of the People's Republic of China and the conventional linkages between China and the "Overseas Chinese" are also examined. Additionally, China-ASEAN relations are analyzed in order to identify the factors influencing these relations. Important statements, regulations and treaties regarding China and the ethnic Chinese in Southeast Asia are also included.

1985 Limp S\$25.00/US\$14.00

\section{Please send orders to: SINGAPORE UNIVERSITY PRESS PTE LTD NATIONAL UNIVERSITY OF SINGAPORE KENT RIDGE SINGAPORE 0511}




\section{Asian Studies from Princeton}

\section{Six Dynasties Poetry Kang-i Sun Chang}

"This study is, to my knowledge, the first in English or any Western language to situate these poets in the larger context of the entire period. The work establishes Dr. Chang as one of the three or four best scholars writing on traditional Chinese poetry today."

- Anthony C. Yu, University of Chicago $\$ 30.00$

\section{The Rāmāyaṇa of Vālmìki}

An Epic of Ancient India

Volume II, Ayodhyākāṇ̣a

Introduction, Translation, and Annotation by

Sheldon I. Pollock

Edited by Robert $P$. Coldman

This is the second of seven volumes that will present a complete and fully annotated translation of the $V \bar{a} / m i k i$ Rãmāyana. Of the seven sections of this great Sanskrit epic, the Ayodhyākānda is the most human, and it remains one of the best introductions to the social and political values of traditional India. This readable translation is accompanied by a commentary that elucidates the various problems of the text, whether philological, aesthetic, or cultural. Princeton Library of Asian Translations $\$ 50.00$

\section{The Flying Phoenix}

\section{Aspects of Chinese}

\section{Sectarianism in Taiwan}

David K. Jordan and

Daniel L. Overmyer

Anthropologist David Jordan and Daniel Overmyer, a historian of religions, present a joint analysis of the most important group of sectarian religious societies in contemporary Taiwan: those that engage in automatic writing seances, or worship by means of the "phoenix" writing implement. Their collaboration makes it possible to view the social and religious world of contemporary believers through interviews or firsthand observation, as well as to consider the literary productions of the sectarians and the relationship of present-day groups to the sectarian tradition in Chinese history. 20 illus., 2 maps. $\$ 39.50$
Agricultural Development and Tenancy Disputes in Japan, 1870-1940

\section{Richard ). Smethurst}

Japan's agricultural economy grew dramatically between the Meiji Restoration and World War II, yet toward the end of this period of growth, especially during the 1920s, tenant farmer/landlord disputes broke out in unprecedented numbers. Challenging the standard interpretation of this phenomenon, Richard Smethurst shows that the growth of a rural market economy did not impoverish the Japanese farmer. 5 maps. $\$ 52.50$

\section{The Fracture of Meaning} Japan's Synthesis of China from the Eighth through the Eighteenth Centuries David Pollack

From the beginning of its recorded history until the opening to the West in the last century, J apan was caught between a love for and a rejection of Chinese civilization. David Pollack argues that the dialectical relationship between the two countries figured more importantly in the Japanese sense of identity and signification than any particular borrowed Chinese cultural materials. 10 illus. $\$ 32.50$

\section{A History of Japanese Literature \\ Volume Two, The Early \\ Middle Ages \\ Jin'ichi Konishi \\ Translated by Aileen Gatten Edited by Earl Miner}

The second of five volumes planned to give a systematic account of Japanese literature from its beginnings to the death of the modern novelist Mishima, this book establishes the character of the literature of the early Middle Ages, from the ninth to the mid. twelf th century. These years were a fertile period marked by the creation of most of the nondramatic kinds of lapanese literature and by the appearance of The Tale of Cenji.

6 half tones, 2 color illus., 1 map. LPE: $\$ 15.00$. C: $\$ 40.00$ 


\section{BRILLIANT JOURNALISTIC ACCOUNTS OF PIVOTAL EVENTS IN MODERN ASIA}

\section{The End of the World That Was}

Six Lives in the Atomic Age A Newsweek Book

By Peter Goldman. A Newsweek Senior Editor looks at the first 40 years of the atomic age through the lives of six people who were directly involved - a physicist who helped build the bomb, a man who loaded it onto the Enola Gay, his daughter who is now an anti-nuclear activist, the navigator who steered the Enola Gay to Hiroshima, and two Japanese who lived through the attack and are still paying a terrible price. An expanded version of the special Newsweek cover story, this book offers an unprecedented view of the human side of the nuclear debate.

(อPLUME 0-452-25806-5

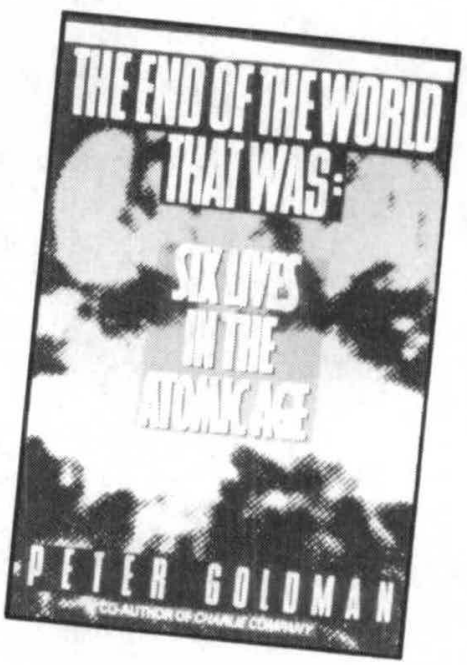

(tent.) \$6.95/\$9.25*

\section{To Get Rich Is Glorious \\ China in the 80s \\ Revised Edition}

By Orville Schell. An absorbing view of the recent transformation of China from the land of "pure" communism under Mao to the land of personal initiative and free enterprise - albeit, Peking style-after the leader's death. "On every page of Schell's new book lies a startling statistic, parallel, or anecdote, some of them enchanting, some of them disturbing... Schell writes a prose so elegant that it is a pleasure to read for its own sake... Must reading." - Chicago Sun-Times. "Contains some of the best recent writing on China .extraordinary." - The Washington Post

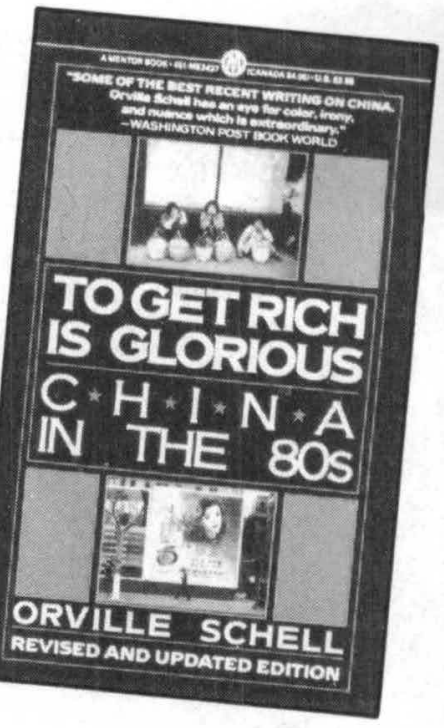

Write to the Education Department at the address below for a free History \& Political Science catalog.

- Price in Canada. Prices subject to change. 


\section{NEW AND NOTEWORTHY FROM KODANSHA}

\section{THE ANATOMY OF SELF}

A Japanese Interpretation by the author of THE ANATOMY OF DEPENDENCE BY TAKEO DOI, M.D.

Foreword by Edward Hall

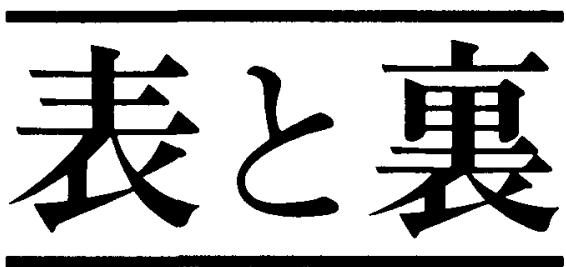

For anyone wishing to gain fresh insights into the relationship between the study of psychology and culture, the relationship between language and mind, as well as that between the Americans and the Japanese, this book can only be considered required reading. Professor Doi has done us all a great favor in writing it.-Edward T. Hall 164 pages; $\$ 14.95$

\section{SINGULAR REBELLION}

\section{A Novel}

BY SAIICHI MARUYA - Translated by Dennis Keene

"Tatta Hitori no Hanran" is a popular best seller in Japan and winner of that country's prestigious Tanizaki Prize. It's comedy with a serious theme, social conformity, offers a hilarious story that tells us more about Japan as it is right now - and how modern Japanese think, feel, and behave-than any other recent Japanese novel.

430 pages: $\$ 17.95$

\section{THE TOKYO WAR CRIMES TRIAL}

An International Symposium

Edited by CHIHIRO HOSOYA, NISUKE ANDO, YASUAKI ONUMA \& RICHARD H. MINEAR

Was the Tokyo Trial a fair legal proceeding, or simple revenge by the Allied victors? Since the main charge of "aggression" was not then a crime under international law, how were the defendants found guilty? These and other issues are considered in this book based on the international symposium held in Tokyo in 1983.

248 pages; $\$ 50.00$

\section{MASAOKA SHIKI}

BY JANINE BEICHMAN

A fascinating look at the life and work of "the father of the modern haiku." 192 pages; $\$ 5.95 \mathrm{pb}$

\section{AT BOOKSTORES \\ OR FROM: 10 EAST 53rd STREET, NEW YORK, NY 10022}




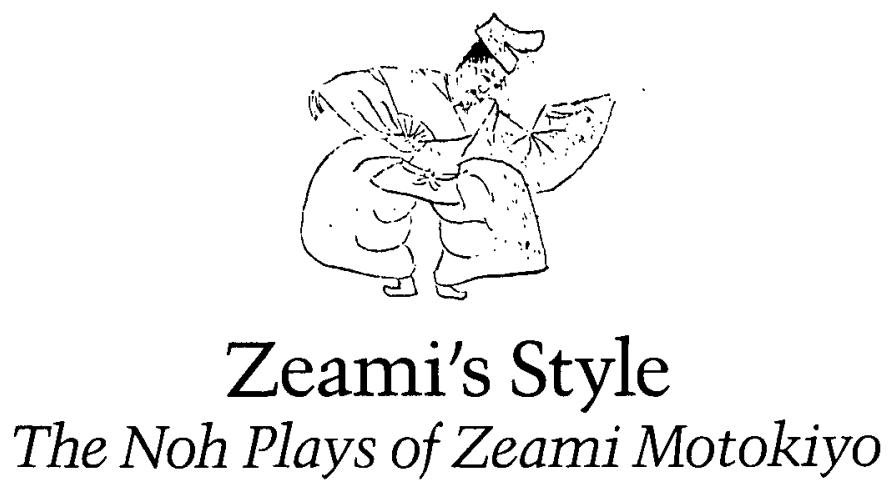

Thomas Blenman Hare. Zeami Motokiyo ( $1363-1443$ ) is generally recognized as the greatest playwright of Japan's classic noh theater. This first full-length study of Zeami in English is a search for his artistic identity, his style. Its main focus is on the dramas themselves, and in particular, the characteristics that distinguish Zeami's work from that of his fellow playwrights. The author first describes Zeami's life, examines the documentary evidence for his authorship, and explains various technical aspects of noh. He then presents complete translations and detailed analyses of three of Zeami's most celebrated plays: Takasago, Izutsu, and Tadanori. Throughout, the author gives quotations and critical examples from many of Zeami's other plays. The book concludes with a discussion of Zeami's style and the relationship between his dramatic theory and his plays. Illus. $\$ 39.50$

\section{Longtime Californ' A Documentary Study of an American Chinatown}

Victor G. and Brett De Bary Nee. Giving voice to Chinese of all ages and from every social group, this fascinating documentary account (first published in I972) remains the classic study of life in San Francisco's Chinatown.

"A pioneering work that does much to correct the long history of misunderstanding, over-simplification, and distortion of the American Chinese community."

-Los Angeles Times

"A panoply of voices from San Francisco's Chinatown, presented in richer and more penetrating detail than anything now in print."-Ezra F. Vogel

"The most vivid, essential guide for anyone who wants to understand the experience of Chinese immigrants in America." - The Christian Science Monitor "I think it is quite marvelous. It makes the whole story of the Chinese in California so alive, so vivid."-Han Suyin

Cloth, \$35.00; paper, \$10.95

\section{Stanford University Press}




\section{Oxford}

\section{Ganeśa}

Lord of Obstacles, Lord of Beginnings

PAUL B. COURTRIGHT, The University of North Carolina at Greensboro. Part animal and part intellectual, an image found in virtually every Indian home, Ganeśa - the elephant-headed god - is one of the most important and popular gods throughout India and Hindu Southeast Asia. This first comprehensive, full-length study of Ganeśa explores the mythology as well as the ritual, the political uses, and the modern and Vedic manifestations of the god, and portrays the intriguing and complex interaction of the diety's many roles.

1985288 pp.; illus. $\$ 29.95$

\section{Wives of the God-King}

The Rituals of the Devadasis of Puri

FREDERIQUE APFFEL MARGLIN, Smith College. Among the 1500 devotees of the Hindu temple and cult of Jagannatha at Puri are a handful of women known as "devadasis" or, literally, "female servants of the diety." This book takes a close look at the curious role of these women to reveal new insights into kingship, power, sexual purity, the status of women, and other central concerns of Hindu religious and cultural life.

1985388 pp.; 16 illus. $\$ 29.95$

\section{Gandhi and His Critics}

B.R.NANDA. Written for all those whose curiosity about Gandhi was sparked by Richard Attenborough's film, or for anyone who would like to know more about this strangely enigmatic leader, this is a fascinating in-depth study of Gandhi's personality and thought. The book explores the evolution and nature of Gandhi's attitudes toward religion, race, the caste system, the British, Muslim separatism and the division of India, social and economic change, nonviolence, and other key issues. 1986186 pp. $\$ 17.95$

\section{The Apparatus of Empire}

\section{Awards of Ranks, Offices and Titles to the Mughal Nobility 1574-1658}

M. ATHAR ALI, Centre of Advanced Study, Aligarh Muslim University. This monumental work provides a systematic and exhaustive guide to the individual officers and appointments - or mansabs - during an eighty-five year period of the Mughal empire. Illuminating the political as well as the social and economic history of the empire, this is an invaluable reference work for students and scholars of the Mughal empire at a particularly powerful point in its history.

1985378 pp. $\$ 59.00$

\section{India and Tibet}

'SIR FRANCIS YOUNGHUSBAND; Introduction by ALASTAIR LAMB, Hatfield Polytechnic. In August 1904 a British military and political expedition entered Tibet under the command of Francis Younghusband, marking the culmination of Britain's efforts to establish good relations with Tibet. Here is Younghusband's own account of the genesis of the expedition, its nature, and the profound consequences of its repudiation after the Chinese invasion of Tibet six years later.

1985530 pp.; 25 plates, 2 maps $\$ 29.95$ 
CORNELL MODERN INDONESIA PROJECT

NEW PUBLICATIONS 1986

THE KENPEITAI IN JAVA AND SUMATRA (Translation Series No. 65) 85 pp. $\$ 8.00$

Translated from the Japanese by Barbara G. Shimer and Guy Hobbs

With an Introduction by Theodore Friend

PRISONERS AT KOTA CANE by Leon Salim (Translation Series No. 66)

112 pp. $\$ 9.00$

Translated by Audrey Kahin

SECOND PRINTING 1986: SUHARTO AND HIS GENERALS: INDONESIA'S MILITAR Y POLITICS, 1975-1983

By David Jenkins. 300 pp. $\$ 12.50$

"No one interested in Indonesian politics can afford not to read this work" Far Eastern Economic Review

Also Available: Dynamics of Dissent in Indonesia: Sawito and the Phantom Coup By David Bourchier. 128 pp. $\$ 9.00$

Write for these and our full publications lists to:

CORNELL MODERN INDONESIA PROJECT

102 West Avenue, Ithaca, N.Y. 14850

\section{Religion \\ $\mathcal{E}$ \\ Modernization IN SOUTHEAST ASIA}

\section{Fred R. von der Mehden}

VON DER MEHDEN focuses on Buddhism, Islam, and Christianity in five countries-Burma, Thailand, Malaysia, Indonesia, and the Philippines-to re-examine the impact of religion on modernization. His findings greatly revise many post-World War II social scientists' contention that religion acts as a hindrance to modernization. Of particular value will be von der Mehden's careful identification and comparison of basic tenets in these countries with regard to religious institutions, popular beliefs, popular practices, and the manipulation of religious symbols.

232 pages, tables, bibliog., index

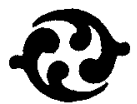

Cloth $\$ 29.95$ Paper $\$ 14.95$

$\begin{array}{lllllllllllllllllllllll}S & Y & R & A & C & U & S & E & U & N & I & V & E & R & S & I & T & Y & P & R & E & S & S\end{array}$ 1600 Jamesville Avenue, Syracuse, New York 13244-5160 


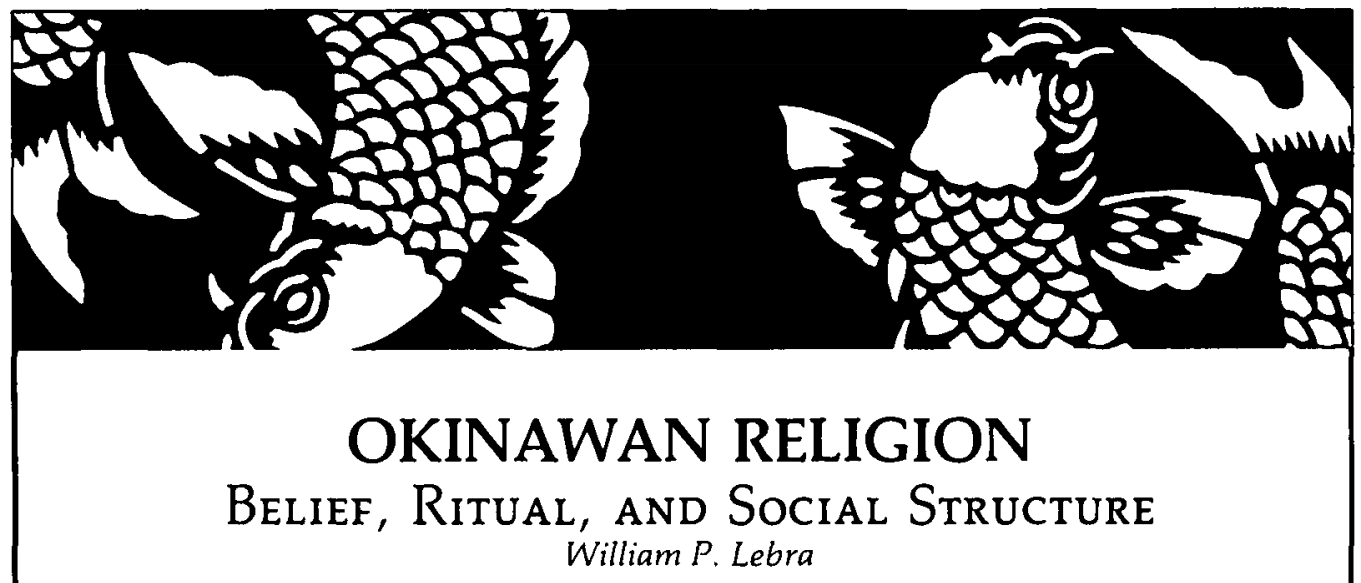

"A notable contribution to research on the Ryuku Islands, to studies of religion, and to East Asian culture history." - American Anthropologist \$8.95, paper

\section{JAPANESE ANTIQUES With a Guide to Shops Revised Edition \\ Patricia Salmon \\ Distributed for Art International Publishers}

A new edition of this concise, well-illustrated directory to the world of Japanese antiques. \$12.95, paper

\section{ZEN ACTION/ZEN PERSON \\ T. P. Kasulis}

"A must for any reading list dealing seriously with Buddhism or Japanese culture." - Choice NOW IN PAPER \$7.95

\section{WOMEN IN ASIA AND THE PACIFIC Towards an East-West Dialogue \\ Madeleine J. Goodman, editor \\ Distributed for the Women's Studies Program, University of Hawaii}

A collection of practical and theoretical studies representing a wide spectrum of views on international feminism. $\$ 17.50$, paper

TO ORDER: Send check or money order, plus $\$ 1.00$ per book for shipping. VISA and MasterCard also accepted (include acct. no., exp. date, and signature).

\section{UNIVERSITY OF HAWAII PRESS}

2840 Kolowalu Street, Honolulu, Hawaii 96822 


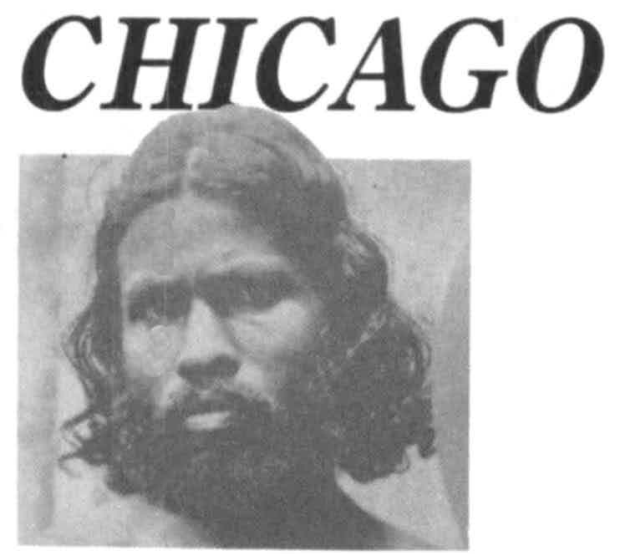

SRI LANKA-

Ethnic Fratricide and the

Dismantling of Democracy

S. J. Tambiah

"Stanley Tambiah's passionate analysis of Sinhalese-Tamil conflicts in Sri Lanka represents a model for explaining much of the political violence in our time."

-Milton Singer

Cloth $\$ 17.95$ (est.)

184 pages (est.) 1 map

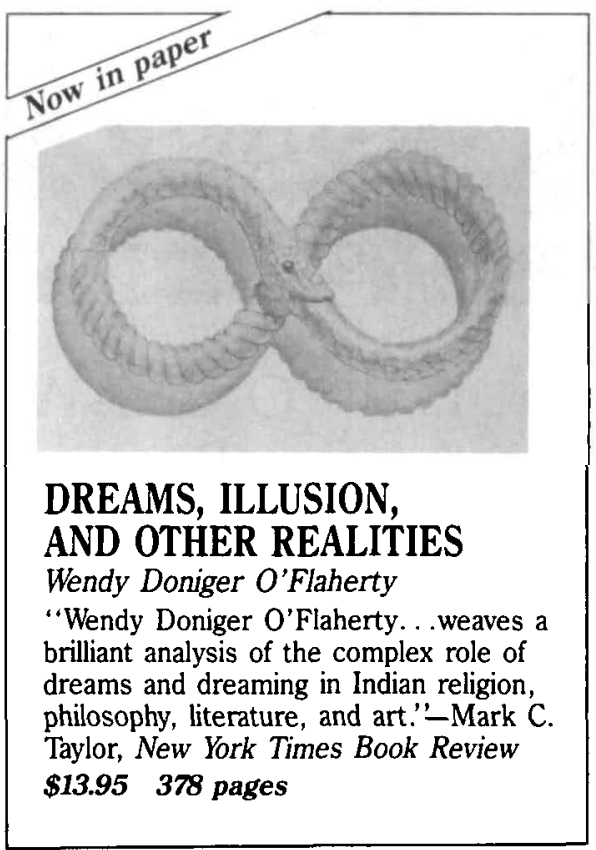

The University of CHUCAGO Press

\section{RECENT BOOKS FROM GROVE PRESS}

The Crazy Iris and Other Stories of the Atomic Aftermath, introduction by Kenzaburō Ōe, ed. Seven of Japan's best writers re-create the impact of the atomic bombings of Hiroshima and Nagasaki on the daily lives of peasants, city professionals, artists, children and families. Kenzaburō $\bar{O} \mathbf{e}$ is the author of $A$ Personal Matter and Teach Us to Outgrow Our Madness. $\$ 6.95$ paper/204 pp./ISBN: 0-394-62075-5; $\$ 22.50$ cloth/ISBN: 0-394-54944-9.

Bankei Zen: Translations from the Record of Bankei, Peter Haskel, tr., Yoshito Hakeda, ed. The teachings of the eccentric Bankei (1622-1693), whom D. T. Suzuki has ranked among Japan's greatest Zen masters. ". . Bankei's unique teaching seems particularly appropriate to our time." -Nancy Wilson Ross. \$8.95 paper/196 pp./ISBN: 0-394-62493-9; \$27.50 cloth/ISBN: 0-394-53524-3.

Alone with Others: An Existential Approach to Buddhism, Stephen Batchelor. A contemporary guide to the timeless message of Buddhism and its relevance in human relations. $\$ 5.95$ paper $/ 143$ pp./ISBN: 0-394-62457-2.

Hare Krishna, Hare Krishna: Five Distinguished Scholars on the Krishna Movement in the West Steven Gelberg, ed. Harvey Cox, A.L. Basham, Thomas J. Hopkins, Larry D. Shinn, and Srivatsa Cosvami provide considerable insight into the origin and background of the Hare Krishna movement and the controversies surrounding it. $\$ 7.95$ paper/276 pp./ISBN: 0-394-62454-8.

World of the Buddha: An Introduction to Buddhist Literature, Lucien Stryk, ed. An unusually broad selection of texts from the vast body of Buddhist literature. ". . . A fine reference book for both the beginning and advanced student." -Choice. \$9.95 paper/423 pp.//SBN: 0-394-17974-9.

Zen Poems of China and Japan: The Crane's Bill, Lucien Stryk, ed. 150 poems reflecting the individual insights of famed monks and masters through the ages, from the 9 th century to the 19th. \$4.95 paper/143 pp. ISBN: 0-394-17912-9.

Grove Press, Inc., 196 West Houston Street, New York, N.Y. 10014 


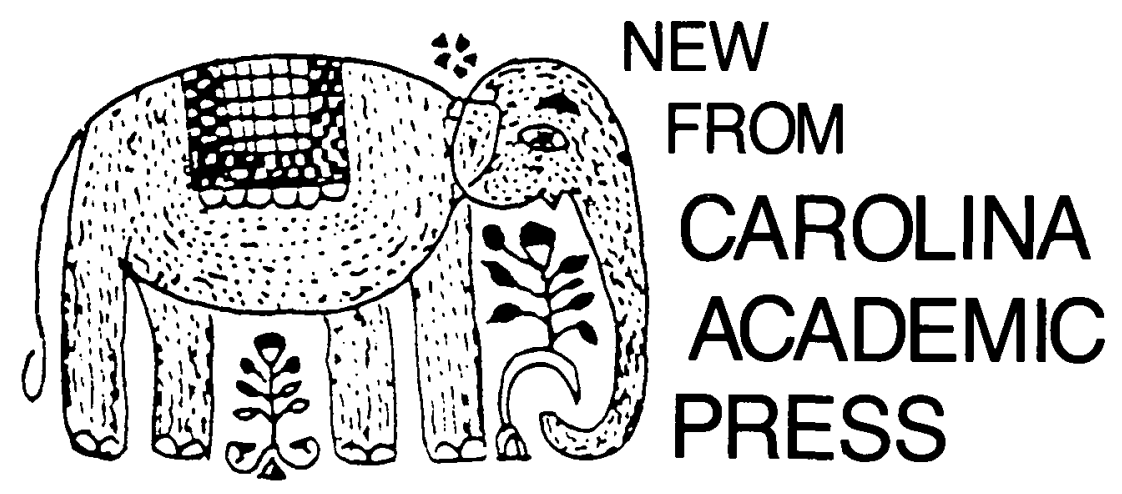

\section{FOOD, SOCIETY \& CULTURE}

R.S. Khare and M.S.A. Rao (eds.)

In studying the food systems of South Asia, the articles in this volume address a wide range of food-related questions and reflect recent trends in anthropological research on food and nutrition. Topics include: socio-religious aspects of sacred food in two Krishnaite sects; changes in food habits among migrants; aspects of cultural economy and food use; hospitality, charity and rationing; the meaning of Muslim feasts in Old Delhi; and food, politics and pilgrimage in South India, 1350-1650 A.D. $1986 \quad 344 \mathrm{pp}$ tables, bibliography, index $\$ 34.95$

\section{KULLI An Exploration of an Ancient Civilization in South Asia \\ Gregory L. Possehl Located in the hills of southern Baluchistan, the sites of Kulli and Mehi are termed the "Kulli Complex" because of the dynamic cultural dimension of the area. Possehl discusses Kulli not only in archaeological terms, but also in terms of the role it played in trade and urbanization in the third millennium. Illustrated with 89 photo- graphs and over 150 line drawings. $1986 \quad 182$ pp quarto $\$ 29.75$}

\section{ETHNICITY, NATIONALISM,} AND THE PAKHTUNS

Stephen Rittenberg In this examination of the relationship among ethnicity, religion and nationalism in India's North-West Frontier Province, Rittenberg examines the ways in which traditional factional and class conflicts structured the politics of the nationalist era and discusses the distinctive role religious leaders played in Frontier society. September $1986286 \mathrm{pp}$ tables, bibliography, index $\$ 27.75$

\section{MADAGASCAR \\ Society and History \\ Conrad Kottak et al. (eds.)}

An important addition to our knowledge of the Indian Ocean Basin as a cultural zone, this volume shows the significant Asian origins of Madagascar's culture. Topics discussed include: cultural tenacity, diversification and evolution, history, and social structure and process. Abstracts are provided in English, French and Malagasy. $1986451 \mathrm{pp}$ tables, bibliography, index $\$ 39.95(\mathrm{c}), \$ 14.75(\mathrm{p})$ 


\section{Bibliography and Index of Mainland Southeast Asian Languages and Linguistics}

\section{Franklin E. Huffman}

A comprehensive, meticulously detailed bibliography covering writings from all over the world, and from the earliest known documents to the present, on the one thousand or so languages of Mainland Southeast Asia, with relevant material also from the fields of ethnography, history, and literature. Compiled over a ten-year period by a preeminent scholar of Southeast Asian languages, this volume will be an important reference book for general linguistics as well as for all students of Southeast Asia. $\$ 35.00$

\section{Peasant Protest in Japan, I590-I884}

Herbert P. Bix

In the first book in English in almost half a century to study the full evolution of peasant protest in Japan, Bix looks at Japan's rural and urban uprisings over the course of its transition from late feudal to early capitalist socicty.

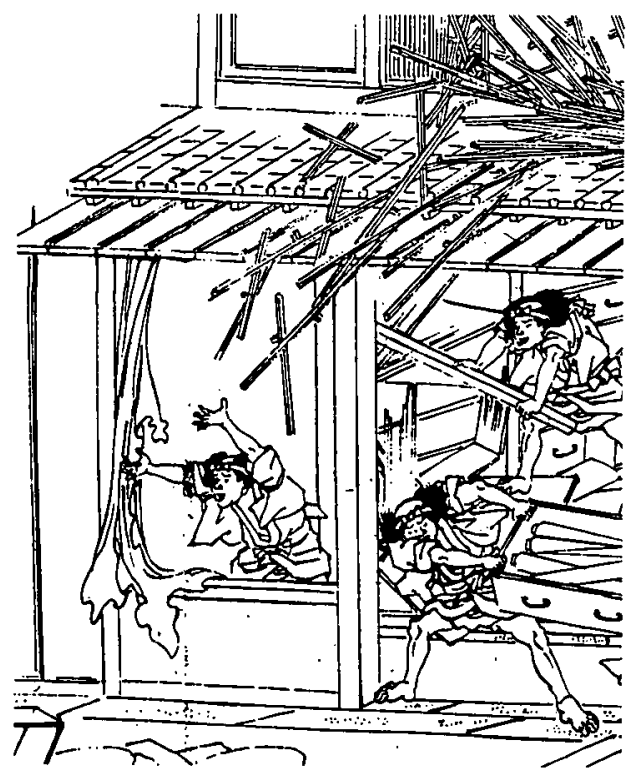

His cogent analysis deepens our understanding of the nature of Japanese feudalism and prewar capitalism and offers a major reassessment of the role of the peasantry and of class struggle in the making of modern Japan. $\$ 30.00$

\section{Studies of Shang Archaeology}

Selected Papers from the International Conference on Shang Civilization

\section{edited by K. C. Chang}

The newest data and major discoveries pertaining to Shang archacology are presented in essays by internationally known specialists on topics ranging from the nature of Erh-li-t'ou culture to the Shang city at Cheng-chou, from the Shang cemetery system to various aspects of Tomb Number Five excavated in 1976 at Yin-hsu. The book defines the field in essential and systematic ways for those interested in Chinese archaeology, history, and art. 63 figs. $\$ 30.00$

\section{Eastern Zhou and Qin Civilizations}

\author{
Li Xueqin \\ translated by K. C. Chang
}

China's foremost authority on Eastern Zhou and $Q$ in discusses new archacological finds and inscriptional data from these periods, incorporating them for the first time into a geographical and chronological framework that conforms with textual details. A landmark study, essential for historians of ancient China, archacologists, art historians, and antiquarians. 212 figs. \$55.00

Early Chinese Civilization Series

\section{Soviet Power and the Third World}

\section{Rajan Menon}

Drawing extensively on Soviet writings and on discussions with Soviet scholars, Rajan Menon analyzes Soviet military policy toward the Third World and reaches the surprising and provocative conclusion that, whilc the focus of Soviet military priorities continues to be on the United States, China, Japan, and Europe, intervention in the Third World is not a goal of paramount importance for the USSR. \$20.00

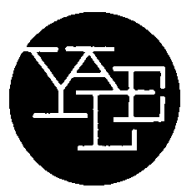

Yale University Press

Dept. 209

92A Yale Station

New Haven, C C o6ৎ20 


\section{New Yale Paperbacks \\ Economic Growth in the Third World: An Introduction}

\section{Lloyd G. Reynolds}

The first comprehensive overview of third world economic growth. After identifying three phases of economic growth, Reynolds analyzes issues pertaining to economic growth in the third world: for example, the role that was played by colonial rule or its absence, by political leadership, and by opportunities for foreign trade; the factors that enabled certain countries to grow faster than others; and what government can do to promote cconomic growth. $\$ 24.00$ cloth; $\$ 7.95$ paper

A Publication of the Economic Growth Center

\section{Shicism and Social Protest}

cdited by Juan R. I. Cole and Nikki R. Keddie This timcly and important book presents the first overview of Shici political activism in the countries where it has been most significant. The contributors present up-to-date informarion on the factors involved in Shi' ism's recent movement away from quietism and toward an active involvement in politics.

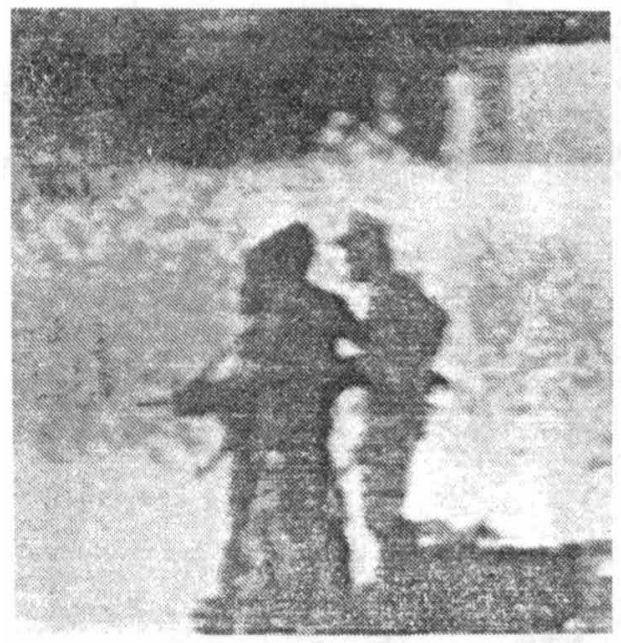

"A valuable survey of contemporary Shi' $i$ political movements in historical context,... [and] a useful guide to the largely unexplored terrain of Shi' $i$ history and tradition behind today's headlines in the Middle East." - Gary G. Sick $\$ 40.00$ cloth; $\$ 12.95$ paper

\section{Thailand: A Short History}

David K. Wyatt

"The first comprehensive history of Thailand to appear in more than half a century." -M. R. Woodward, Choice

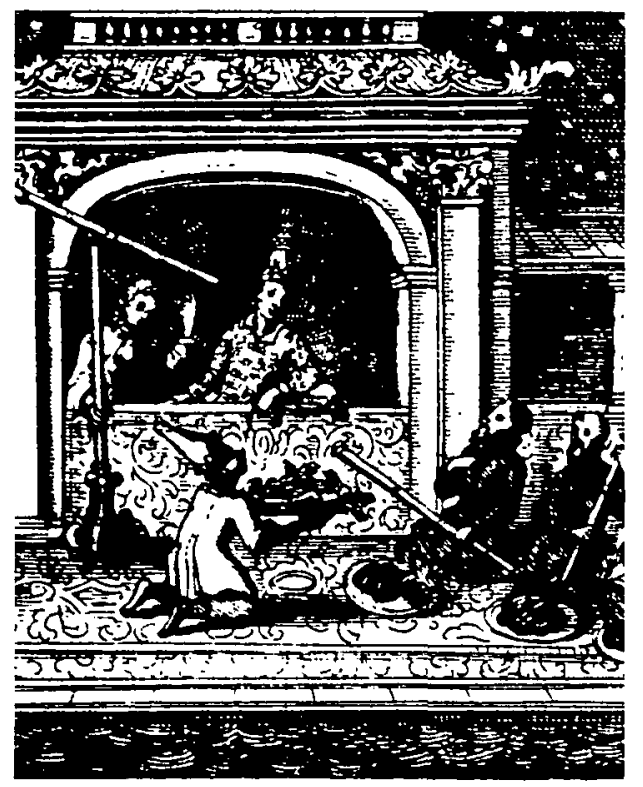

"If history should help us understand the present, then this book succeeds admirably in that task; we come away from reading it with a clearer understanding of where Thailand stands in relation to its neighbors, who the Thai people are, how the Thai government cvolved into its present form. . . . A very readable account." - James Stent, Asian Wall Street Journal $\$ 12.95$

\section{China's Foreign Relations in the 1980 s}

edited by Harry Harding

The major factors that shape the foreign policies of China are analyzed in this timely book by Michael Hunt, Kenneth Lieberthal, Bruce Reynolds, Steven Levine, Jonathan Pollack, and Harry Harding.

"The China Council of the Asia Society ... has sponsored this illuminating collection of cssays on China's foreign relations. . . . This book is a first-rate introduction to the subject for the nonspecialist and will remain so for several years to come." - James R. Townsend, Journal of Asian Studies $\$ 8.95$ 


\section{Understanding China Through Cartoons C.E. BLED}

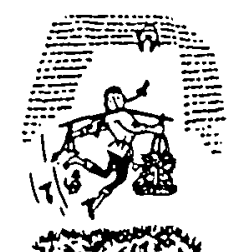

Analysis of 354 cartoons from China's national newspaper people's Daily covering urban \& rural China - Housing, Changing family \& social structures, foreign influences, Problems of modernization such as work ethics, bureaucracy, resurging elet ism, \& the need for personnel \& management reorganization \& reor ientation.

This is not a book for art appreciation. It is a fascinating portrayal of mass communication at work. A required reading for sinologists and international ists. $\$ 9.95$ (Quant ity discounts) (Question Guide Study Supplement available on request with book order. No additional charge.)

ISBN 0-9691964-0-0

Society For A Better Understanding of China, 206 Queen Elizabeth Driveway, Ottawa, Ontario, Canada KIM 0 J7.

\section{PUBLISHED FOR THE WORLD BANK CHINA}

Long-Term Development Issues and Options

$\boldsymbol{E}$ xamines critical issues over the next twenty years in virtually every aspect of China's economy and finds that success in effectively using available resources, especially people, will depend largely on success in reforming the system of economic management. It is, nonetheless, vital to guard against losing the strengths of the existing system-its capacity to mobilize resources and to help the poor-in the course of overcoming its weaknesses.

\$29.95 hardcover

$\$ 14.95$ paperback

Now in paperback

\section{RURAL DEVELOPMENT IN CHINA DWIGHT H. PERKINS AND SHAHID YUSUF}

Analyzes China's agricultural performance since the founding of the People's Republic in 1949 and traces the progress back to the technology and other sources that made it possible.

Perkins and Yusuf examine the political and organizational means that enabled the Chinese to mobilize labor for development purposes and describe what has happened to the quality of life of rural residents.

$\$ 12.00$ paperback $\$ 25.00$ hardcover 
A Fascinating Personal
Memoir of Two Powerful Japanese Families.

From the feudal infighting of the Tokugawa shoguns to today's international eminence, Japan has utterly transformed itself over the last century and a half.

In chronicling the involvement of her own family members in the period's tumultuous events, Haru Reischauer provides an endlessly fascinating personal perspective on this era of unprecedented change.

Her two grandfathers - one a provincial samurai, the other a silk merchant residing in the United States produced children and grandchildren of exceptional talent and energy. Their activities include statecraft, politics, education, finance, art, culture, and the development of such major industrial entities as Mitsubishi and Kawasaki.

Altogether an amazingly multi-faceted mirror of the rise of modern Japan. Copiously illustrated with the author's personal photographs. Belknap $\$ 20.00$ Samurai and Silk A Japanese and American Heritage University Haru Matsukata Reischauer 


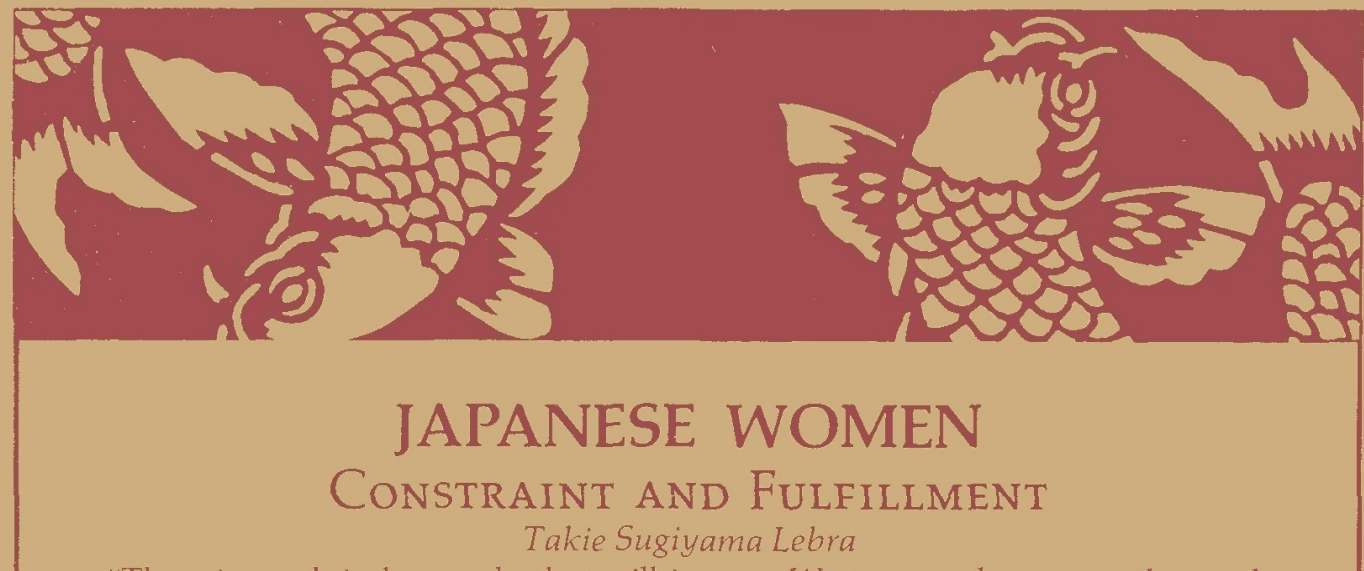

"There is much in her study that will interest Western readers . . . a thorough and surprising look into another world." - N.Y. Times Book Review

\$18.95, cloth; NOW IN PAPER \$9.50

\section{LAW AND THE STATE IN TRADITIONAL EAST ASIA VOLUME I \\ Six Studies on the Sources of East Asian Law \\ Brian E. McKnight, editor}

Six papers outlining the varied sources of law in Japan, China, Korea, and Viet Nam. \$18.00, paper

\section{SHŌBŌGENZŌ \\ ZeN Essays by Dōgen \\ Translated by Thomas Cleary}

Translations of 13 essays from this classic by the 13 th century Zen master. S14.00, cloth

\section{THE BURDEN OF PROOF \\ The Vargas-Laurel Collaboration Case Teodoro A. Agoncillo \\ Distributed for the Univ. of the Philippines Press}

The story of the Sugamo detainees, who were imprisoned and tried by the U.S. for collaborating with the enemy during the World War II Japanese occupation of the Philippines. \$28.00, cloth

TO ORDER: Send check or money order, plus $\$ 1.00$ per book for shipping. VISA and MasterCard also accepted (include acct. no., exp. date, and signature). 